\title{
РЭЛІГІЙНАЯ СВЯТОЧНАЯ КУЛЬТУРА Ў МЯСТЭЧКАХ ЗАХОДНЯЙ БЕЛАРУСІ
}

(1921-1939)

\section{Г. С. КАСЯНОЎСКАЯ}

\section{Гродзенскі дзяржаўны ўніверсітэт імя Янкі Купаль, г. Гродна, Беларусь}

Мястэчка, шырока пашыраны калісьці тып паселішча, сімвалізуе цэую эпоху ў гісторыі нашай краіны. На працягу XVI - пачатку XX ст. мястэчкі як асобныя тыпы паселішчаў былі часткай культурнага развіцця беларускага народа. У новых умовах гістарычнай рэчаіснасці ў 1921-1939 гг. заходнебеларускія мястэчкі захавалі сваю традыцыйнасць і асобнасць, і іх развіццё адбывалася ва ўмовах палітыкі польскай дзяржавы, накіраванай на сацыя-культурную інтэграцыю Заходняй Беларусі ў складзе Польшчы. Тым не менш міжваенны час стаў апошнім перыядам гістарычнага развіцця заходнебеларускіх мястэчак як асобага тыпу паселішчаў. Пасля далучэння Заходняй Беларусі да БССР у 1939 г. мястэчкі як адміністрацыйныя адзінкі былі скасаваны.

Неад’емлімай і важнай часткай паўсядзеннага жыцця насельніцтва мястэчак была рэлігія і рэлігійныя святы, якія ў большай ступені паказвалі разнастайнасць традыцыйнай культуры поліэтнічнага насельніцтва мястэчак. У мястэчках святкаваліся праваслаўныя, каталіцкія, іўдзейскія і мусульманскія святы. Успаміны местачкоўцаў адлюстроўваюць мясцовыя асаблівасці, звычаі і традыцыі ў правядзенні рэлігійных свят.

Асноўнымі святамі, якія адзначалі ўсе местачкоўцы-хрысціяне, былі Каляды, Вялікдзень, Троіца (Сёмуха, Пяцідзясятніца), Спас, некаторыя храмавыя святы.

Доўгачаканымі святамі для местачкоўцаў былі Каляды. Каляды святкаваліся штогод два тыдні 324 снежня па 7 студзеня. Кульмінацыяй Каляд, самым святочным днем было Раство. У дзень Раства забаранялася працаваць, гэта лічылася “вялікім грахом”. 3 самай раніцы гаспадыні варылі куцю. Куцею местачкоуцы называлі тры святочных вечара: перад Раством, Новым годам, святам “Трох каралей”. Кожная куця мела свае асаблівасці прыгатавання i падачы. Куця перад Раством мела назву “Бедная куця” і падавалася 24 снежня на постную вячэру. 3 першай зоркай на небе гаспадар нес ў хату шматок сена і клаў яго на стол, а гаспадыня засцілала стол белым абрусам. Пасля агульнай малітвы пачыналася сямейная вячэра, а потым спявалі калядныя песні, складвалі віншаванні і абменьваліся падарункамі. На святочным стале павінна было стаяць не меньш за сем страў. Звычайна гэта былі: падліўка 3 грыбамі, кісель, крупнік з рыбай, манная каша с макам (якую і называлі куцею), варэнікі 3 макам, селядзец, смажаная рыба. Нават у самай беднай сям’i, каб колькасць страў даходзіла да сямі, дапускалася падаваць адныя ж і тыя стравы некалькі разоў.

Сімвалам Раства і Новага года была елка, якую гаспадар прыносіў з лесу. Вучні у школах рабілі цацкі на елку, гірлянды для упрыгожвання хат і вуліц. Цацкі, як і саму елку, можна было купіць у магазіне. "Падарункавая ліхаманка" перад Калядамі і Новым годам была характэрнай для жыхароў мястэчак. Духі, радыёапаратура, швейныя машынкі, адзенне, абутак, цацкі для дзяцей, гадзіннікі, фотаапараты, посуд - гэтыя рэчы часцей за ўсё узгадваліся местачкоўцамі як папулярныя падарункі пад калядную елку.

Жыхары Міра аб святкаванні Каляд ўспаміналі: “На Каляды елку ўррыгожвалі, лапінкі елкі вешалі на дзверы. Пяклі булкі з макам, рыбу ў цесце, смажанкі з макам, куцию. У святочны вечар перад вячэрай мы садзіліся на покуцьь, i папа з парога пачьнау “сеяць”, гэта значьиць кідащь зерне. Мы фартухі трымалі, $і$ у каго колькі у фрартуху зерня акажащиа, столькі і баранчыкаў будзе. Цэль дзень елі поснае, ніякага мяса, на наступнь дзень каўбаса з верашчакою і куция з салам. Пост иягнуусся 6 тылняй. Абавязкова на вячэру елі булкі з макам. Ішлі у клуб на таниы на ўсю ноч, перад гэтым выпівалі водкі па 3 шкляначкі 3 чакушкі.... Тады столькі п'яніц не было, як зараз, усе было культурна [1, с. 55]. 
На Каляды местачкоўцы варажылі, прычым варажбой займаліся як мужчыны (варажылі на ураджай), так і жанчыны, асабліва моладзь. Спосабаў варажбы было мноства. Напрыклад, у Паставах маладыя дзяўчыны, каб даведацца, калі выйдуць замуж, для варажбы бралі ката, закрывалі яму вочы і пускалі ў цэнтр хаты. Калі кот скочыць у дзверы, дзяўчына ў гэтым годзе выйдзе замуж, калі на печ - яшчэ год “сядзець дзяўчыне на пячы пад прыглядам баиьккой [2].

Вечарам моладзь праводзіла розныя калядныя ігрышчы. Найбольш папулярнай была “гульня ў фанты”: маладыя хлопцы і дзяўчыны хадзілі ад хаты да хаты з надзеяй “украсиі"” сані ці воз, ці зняць брамку з плоту. “Выкрадзеныл" рэчы ў сям’і маладой дзяўчыны падкідваліся хлопцу, якому яна падабалася і наадварот. Раніцай моладзь хадзіла па мястэчку і шукала страчаныя рэчы. Вось так нярэдка адбывалася першая сустрэча маладых і першае каханне.

Жыхары мястэчка Азеры Беластоцкага ваяводства ўспаміналі: “На святкаванне Новага года з 1935 па 1938 г. штогод з Гродна прыязджалі артысты з батлейкай. Святкаванне новага года адбывалася у чыесиі хаце, альбо у доме людовым. Кожны, хто збіраўся на сільвестровы вечар, павінен быу прынесиі штосиі з ежы. А поўначы складваліся віншаванні, былі танщьы да самай раніщьь” [3, с. 78].

Святам усіх святаў лічыўся Вялікдзень, якому папярэднічалі 7 тыдняў посту. Перад самым вялікаднем тыдзень лічыўся святочным. Асабліва - чацверг, які местачкоўцы называлі “чысты чацверг”. У чацверг гаспадыня перад ўвасходам сонца будзіла сваіх дачок i яны беглі да бліжэйшага ручая, каб памыцца бягучай вадой. Лічылася, што прыродная вада ў гэты дзень “святая”, яна “дае прыгажосць $i$ здароўе на иээлы год”. У пятніцу перад Вялікдзеням гаспадыня чысціла печ. Гаспадар браў лапату, якой падаваўся хлеб у печ, выходзіў на двор і счышчаў рэшткі снега. 3 рэштак снега рабіўся кругляш, які гаспадар клаў на лапату і нес ў хату, i закладваў яго ў печ. Такім абрадам сям'я развітвалася 3 зімою i запрашала ў хату вясну, каб добры настрой і пачуцце цеплыні з вясною прыйшло да ўсіх членаў сям'i.

Святкаваўся Вялікдзень тры дні: у першы дзень не выходзілі з дому і праводзілі час толькі са сваей сям'ей. У ноч з суботы на надзелю праваслаўныя вернікі спяшаліся ў царкву ці касцел, каб пасвенціць яйкі і іншыя стравы. Моладзь тлумілася ўсю ноч вакол царквы, каб абмяняцца яйкамі. На другі дзень з'язджаліся сваякі, усе “хрыстосаваліся” і дарылі адзін аднаму яйкі. У гэты дзень было прынята хадзіць у госці ці прымаць іх у сябе. Праваслаўныя вернікі на другі дзень свята хадзілі на могілкі, паміналі ўсопшых і насілі туды святочную ежу. Вечарам моладзь хадзіла па хатах з валачобнымі песнямі, у якіх славілі гаспадароў і Вялікдзень. На трэці дзень свята пачыналася вялікае гулянне і ўсе выходзілі на вуліцы, ладзіліся святочныя танцы.

Сёмуха (Троіца ці Пяцідзесятніца) належала да ліку святаў, якія не мелі выразна акрэсленай даты і адзначаліся ў залежнасці ад Вялікадня. Сёмушныя святы ахоплівалі каляндарны перыяд, які ў местачкоўцаў меў вельмі ёмістую назву - пралецце. Релігійнае свята Семуха адкрывала цыкл календарных свят: Св. Міколы, Купалле, Св. Пятра. У залежнасці ад мясцовых традыцый Сёмуха, або Тройца, адзначалася адзін, тры дні ці тыдзень. Як ні адно свята семушныя дні былі насычаны мясцовымі традыцыямі і абрадамі. Семуху называлі “Зяленымі святкамі”. Папулярным у мястэчках быў звычай упрыгожваць жытло і гаспадарчыя пабудовы, культавыя збудаванні зелянінай. Рабілася гэта для добрага ўраджаю. Ушанаванне продкаў - абавязковы элемент “Зяленых святкаў”. У гэты дзень вернікі ішлі на могілкі, запальвалі свечкі, маліліся, прасілі сіл у продкаў, дзякавалі за добры ўраджай і гаспадарку. У местачкоўцаў было павер'е, што на Сёмуху душы памерлых вярталіся на землю да сваіх каранеў. У некаторых мясцовасцях лічылася, што душы памерлых вярталіся ў выглядзе русалак, дамавых і лясных пачвар. Таму, тыдзень “Зяленых святак” называлі “тыднем русалак”. Каб супакоіць памерлых, прыбіралі іх магілы, высаджвалі жывыя кветкі, запальвалі свечкі, прыносілі ежу на могілкі. На трэці дзень свята гаспадары арганізоўвалі сямейную вячэру з удзелам продкаў т.з. “вясновыя дзяды”. Перад 
тым як сесці за стол, гаспадар выходзіў з хаты на двор і гаварыў наступныя словы: “Мама, тата, дзед і прадзед, і іншыя душы, якія тут, у гэтай хаще прыбывалі, хлеб $і$ соль разам ужывалі, мы шчыра запрашаем павячэраць” [4]. Пастухі ў гэты тыдзень на полі палілі вогнішчы так, быццам адганялі “злыя душы”, каб яны не нанеслі ўрон жывеле.

У некаторых мястэчках былі свае мясцовыя асаблівасці святкавання Семухі. Так, напрыклад, у мястэчку Любча Навагрудскага ваяводства на трэці дзень пасля Семухі адзначалася прастольнае свята Падліпкі, на якое збіраліся паломнікі з усіх суседніх весак ад Шчорсаў да Далятыч, ад Навагрудка да Вільні. Гэта быў крыжовы ход да Падліпскай царквы. Апошнія паўкіламетры шляху вернікі пераадольвалі на каленях. Каля самой царквы ў гэты дзень адбываўся вялікі кірмаш [5, с. 124].

Найбольш блізкімі паміж сабой, натуральна, былі каталіцкія і праваслаўныя святы. Так, жыхар мястэчка Валожын Навагрудскага ваяводства У. Косік ўспамінаў: “Mы былі праваслаўнымі, але хадзілі у госиі $і$ да паляка-католіка на яго святы, а ён у сваю чаргу - да нас. Навогул, канфесійная прыналежнасиь асаблівага значэння не мела. У мястэчку быу касцёл і дзве цуарквы, а таксама праваслаўная каплічка на могілках. Можна было свабодна хадзіщь $і$ у изаркву, $і$ у касцёл, але ксёндз злаваўся, калі каталічка брала шлюб з праваслаўным” [6, c. 94].

Паводле вусных успамінаў, зразумелымі для ўспрымання 3 боку местачкоўцаўхрысцян была святочная культура татар-мусульман. Жыхары Міра ўспаміналі: “Варожасиі паміж намі $і$ татарамі не было. Размайлялі яны паміж сабой $i$ з намі па-намаму, але маліліся па-свойму. [....] Татары працавалі як пчолкі. Яны былі галоўнымі агароднікамі. [....] Татары адзначаюиь свае святы. Родныя прыязджающь, иіха, прыгожа. У іх Байрам быуу. Спіртнога няма ніколі на стале. У іх ніколі ніякіх скокаўне было, не сваращца. Самае моднае y татар - скрыпка. Іх нацыянальнае блюда - макаронка з мясам - перакачнік. Кожную пятніиу святкавалі" [1, с. 44].

Жыхар мястэчка Новая Мыш Навагрудскага ваяводства Іосіф Смольскі (1913 г.н.) нарадзіўся ў татарскай сям'і. Аб святкаванні рэлігійных святаў успамінаў: “На службу хадзілі за 20 км. у Ляхавічы у мячэиь кожную пятніщу штотылзень. Галоўнымі святамі былі: Курбан-байрам, Ураза-байрам, Ашура. Маліліся на арабскай мове з удзелам мульл. На свята да нас прыходзілі сваякі - пераважна брать майго баџькі. Мама гатавала на свять нацьяннальныл стравы: калдуны, бяляшы і бліны з індычкай. Алкаголя на святы не ужывалася увогуле” [7, с. 562].

Найбольш адрознай, але не варожай для местачкоўцаў-хрысціянаў была святочная культура яўрэяў. Яўрэі адзначалі некалькі важных свят: Пурым, Рош-Хашана (Новы год), Ём-Кіпур (Судны дзень), Сукот (Кучкі).

Незразумелыя i, разам 3 тым, дзіўныя для палякаў і беларусаў традыцыі яўрэяў станавіліся нагодай для жартаў. Міране на гэты выпадак ўспаміналі: “Восенню свята ix было, “кучкі" называлася, то яны адкрывалі вокны на вуліџы, накладвалі кучу хворасту, пасля запальвалі яго, мокры ен усе дыміў, дыміў, а яны уусе маліліся. Яны ў дварах будавалі спецыяльныя шалашы і уввесь тылдзень там маліліся. Яны молящча, иээлыя сем'і і родныл, пры свечках, але самім запальваџь і тушыщь іх ім нельга. Пагэтаму яны за грошы клікалі дзяцей. [....] Яны рабілі, каб частка даху дому, метры два, падымалася ӱверх, ну а потым, пасля кучак, апускалася. Пакуль кучкі, трымалі адчынены дах. Там яны прымалі ежу, пад дажджом. А дзеиі яшчэ як хуліганілі! Так мы, бывала ідзем са школь [....] $і$ каштанамі, иі палкамі якімі імкнемся туды, у гэту дзірку трапіџь. I яйкі, вядома, не курыныл, назбіраем шпаковых, ад галак [....] Яек назбіраем і туды яйка - плюх! А яны ужо як выскачаць: "Ой, сволач mbl!" I па-габрэйску. I “хам”? і кащапь нас называлі” [1, с. 41-42]. Аднак некаторыя местачкоўцы праяўлялі асаблівую цікаваць да яўрэйскіх святаў і гісторыі іх паходжання. Жыхарка мястэчка Орля ўспамінала: “Свята Кучкі адзначалася восенню і прачягвалася сем дзен. У каго быуу ганак каля хаты, то выносілі там столік, а калі не, то рабілі кучкі (шалаш) на панадворку. Кучкі прыпаміналі яўрэям пра разбіванне шалашой іхнымі продкамі уу час вандройкі з Егіпта иераз пустыню [....] На Суднь дзень усе яўрэі ішлі маліщиа ў бажніщу. 
Там гарэлі тоўстыя паўметровыя свечы. Нашы маладыя жулікі часта пускалі у бажніиу варону альбо голуба. Спалоханая птушка летала па святыні і тушыла свечкі, а яуррэі голасна лямантавалі" [8, с. 181].

Нягледзячы на тое, што яўрэі частавалі мацой сваіх суседзяў неярэяў, трывалымі былі страхі ды забабоны, звязаныя з так званым крывавым нагаворам. Так, напрыклад, дзяцей мястэчка Азеры Беластоцкага ваяводсттва пужалі, што мясцовы яўрэй Цхазын, які жыў каля яўрэйскіх могілак, можа схапіць, засунуць ў бочку з цвікамі і катаць. Тлумачылі, што гэта было яму неабходна, каб прыгатаваць мацу на Кучкі з дзіцячай крыві [3, с. 184].

Яўрэйская маца рыхтавалася на ўсе рэлігійныя святы. Жыхары Орлі ўспаміналі: "Пурылм - аднадзеннае свята за тыдзень перад Пасхай. Пасху старазаконныя святкавалі восем дзен, але у сярэдзіне святкаванняў былі рабочыя дні. Да гэтага свята яўрэі пяклі маиу - такія вельмі тонкія аладкі з мукі, былі посныя і на яйках. На яйках - былі прызначаны для гасией. Посныя аладкі потым таўклі у ступе на куцию $і$ з яе варылі “мацфарфу” - зачірку [...]”[8, c. 181].

Значнае месца ў мемуарнай літаратуры займае тэма шабату i асаблівасцей яго правядзення ў мястэчку. Шабат пачынаўся пасля захода сонца ў пятніцу і доўжыўся да вечара суботы. Штотыдзень яўрэйскай гмінай вызначаўся яўрэй, які вечарам у пятніцу хадзіў па вуліцах мястэчка 3 драўлянай трашчоткай са словамі: “Insiuachaj” і заклікаў вернікаў пачынаць шабат. Гэта быў час закрыцця магазінаў і лавак, і спынення ўсялякай працоўнай дзейнасці. Спыняўся шабат службай у сінагоге, чытаннем адпаведнага фрагмента "Пяцікніжжа". Ежу ў хатах рыхтавалі на вечар пятніцы і на суботу. У Палескім ваяводстве крыніцы сведчаць аб дзейнасці спецыяльнага яўрэйскага таварыства "Szomraj Szabes Hadas", галоўнай функцыяй якога сачыць за правядзеннем шабату у мястэчках. Па успамінам Іцхака Меiр Южука (1925 г.н), жыхара палескага мястэчка Пагост Загародскі, можна даведацца пра працэс прыгатавання да шабату: "Рыхтаващйа да шабату пачыналі з чацвярга. У гэты дзень мая маці купала ўсіх дзящей, лажыла іх спащуь і мыла падлогу. У пятніиу зрана прыходзіла бабуля і дапамагала маці прыгатаващь ежу на пятнічу вечар і суботу. Вечарам мая маці запальвала свечкі, малілася і уся сям'я садзілася за стол. У суботу зранку прыходзіла наша суседка хрысиіянка збірала посуд і недагаркі ад свечак” [9, с. 193].

Хрысціяне паважалі яўрэйскі шабат, аб гэтым сведчыць досыць значная колькасць станоўчых выказванняў i ўспамінаў. Неабходна падкрэсліць, што шабат быў часам нядрэнных заробкаў для хрысціян. Яўрэі нанімалі сярод мясцовага насельніцтва работнікаў, якія падчас шабату займаліся развядзеннем і падтрымліваннем агню і іншай хатняй працай. Плацілі за такую работу нядрэнна, на якую з ахвотай згаджаліся мясцовыя хрысціяне.

У яўрэяў былі жалобныя дні, да якіх з павагай адносілася польскага ўлада. “Дзень

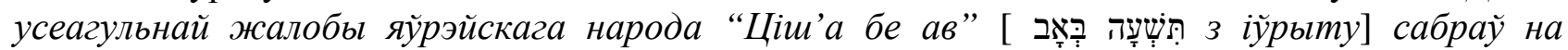
яўрэйскіх могілках 20 ліпеня 1932 г. у мястэчку Льнгмяны каля 2000 яўрэяй, з якіх толькі з Вільні было 500. Польскія уллады дазволілі праводзіщь жалобнае свята $i$ дапамаглі 3 пад'ездам да мястэчка такой колькасиі яўрэяй - пісала газета “Баранавіцкі кур'ер” у 1932 годзе [10].

Такім чынам, рэлігія ў кожнай этнічнай групе мела дамінуючае значэнне i рэгламентавала штодзеннае жыцце. “Бога баяліся”, стараліся жыць так, “каб не прагнявіuь Бога”. Многія гаспадарчыя заняткі адбываліся згодна 3 рэлігійным ці прыродным календаром. Правядзенне кірмашоў у мястэчках залежала ад рэлігійных святаў.

Рэлігійныя святы былі універсальным сродкам перадачы сацыяльнага вопыту 3 пакалення ў пакаленне. Сур'езная падрыхтоўка, працэс святкавання і адносіны да такіх святаў сведчылі аб значнай кансервацыі і закрытасці традыцыйнай культуры местачкоўцаў. Аднак, працэсы індустрыялізацыі і урбанізацыі павялічвалі колькасць формаў баўлення вольнага часу нават пад час святкавання рэлігійных святаў, тым самым паскорылі адаптацыю мясцовага насельніцтва да папулярнай масавай культуры, якая станавілася дамінуючай i камерцыяналізаванай. 


\section{Літаратура}

1. Раманава, I. Мip : гісторыя мястэчка, што расказалі яго жыхары / I. Раманава, І. Махоўская. - Вільня : ЕГУ, 2009. - 248 с.

2. Boże Narodzenie w powecie Postawskim // Kurier Wileński. - 23 grudnia. - 1936. - № 352. s. 8.

3. Gubarewicz, J. Kresowe miasteczko Jeziory / J. Gubarewicz. - Białystok: Prymat, 2006. - 320 s.

4. Kurier Wileński. - 16 maja. - 1937. - s. 6.

5. Куц, Н. Духоўнае жыццё мястэчка Любча ў 20-30 гг. ХХ ст. / Н. Куц // Ян Булгак i культура заходнебеларускага рэгіёну ў канцы XIX ст. і да другой сусветнай вайны : зб. навук. арт. / Гродз. дзярж. ун-т ; рэдкал. : В. В. Швед (адк.рэд) [i інш.]. - Гродна, 2009. C. $117-126$.

6. «За польскім часам...»: Западная Беларусь в воспоминаниях современников / Брест. гос. ун-т А. С. Пушкина; редкол. : Е. С. Роземблат (гл. ред). [и др.]. - Брест: БрГУ, 2019. 172 c.

7. Smolski, J. Moja Nowa Mysz / J. Smolski // Europa nieprowincjonalna: przemiany na ziemiach Wschodnich dawniej Rzeczypospolitej w latach 1772-1999 : praca zbiorowa / J. Smolski [i in.]; pod red. K. Jasiewica. - Warszawa : Wyd-wo Instytuta Studiów Politysznych, 1999. S. 560-565.

8. У новай айчыне. Штодзённае жыццё беларусаў Беласточчыны ў міжваенны перыяд / Пад рэд. В. Луба. - Беласток : Праграмная Рада Тыднёвіка Ніва, 2001. - 300 с.

9. Berendt, G. Żydzi w województwie Poleskim w latach 1921-1939 / G. Berendt // Życie codzienne społecznośći żydowskiej na ziemiach polskich do 1942 roku: praca zbiorowa / Pod red. E. Majcher-Ociesy [i inni]. - Kielcie: Uniwersytet J. Kochanowskiego, 2013. - S. 181-218.

10. 2000 żydów w Łyngmianach // Kurier Baranowicki. - 1932. - 21 lipca. - s. 6.

Навуковы артыкул прысвечаны аналізу рэлігійнай святочнай культуры і яе уплыву на насельніцтва мястэчак Заходняй Беларусі 20-30 гг. ХX ст. Рэлігійныя святы былі універсальным сродкам перадачы сацыяльнага вопыту 3 пакалення ў пакаленне i рэгламентавалі штоддзеннае жыцце местачкоўцаў. У мястэчках святкаваліся хрысціянскія, іўдзейскія і мусульманскія святы. Успаміны местачкоўцаў адлюстроўваюць мясцовыя асаблівасці, звычаі і традыцыі ў правядзенні рэлігійных свят.

The scientific article is devoted to the analysis of religious festive culture and its influence on the townships of Western Belarus in the 20-30 of XX century. Religious holidays were a universal means of transferring social experience from generation to generation and regulated the daily life of local residents. In the townships were celebrated Christian, Jewish and Muslim holidays. The memories of local residents reflect the peculiarities, customs and traditions of holding religious holidays. 